\title{
Influence of application date and adjuvant on chlortoluron residues and quality of winter wheat grain
}

\author{
Wpływ terminu aplikacji oraz dodatku adiuwanta \\ na pozostałości chlorotoluronu i jakość ziarna pszenicy ozimej
}

\author{
Mariusz Kucharski, Jerzy Sadowski, Olga Kalitowska
}

\begin{abstract}
Summary
The aim of the studies was to determine the influence of herbicide application date and adjuvants on weed control efficacy, residues and quality parameters of winter wheat grain. Field experiment was conducted in the years 2010-2012. Chemical weed control in winter wheat was carried out with commercial formulation of chlortoluron (herbicide Tolurex 500 SC). Herbicide was applied separately at recommended and reduced doses and at reduced dose in mixture with adjuvants as a preemergence application in the autumn and as a postemergence treatment in the late autumn and in the spring. Phytotoxicity and efficacy of herbicide and its mixtures with adjuvants were evaluated in the experiments. Moreover, the residue of chlortoluron in soil and grain of winter wheat and wheat grain quality were analyzed. No phytotoxic effects of used herbicide (separately and jointly with adjuvant) and application date on winter wheat were stated. Application of herbicide with adjuvant allowed reducing the herbicide dose (without loss of weed control efficacy). The addition of adjuvants caused a significant increase in the weed control and the herbicide residues in soil and grain samples as compared to the treatments with herbicide that was used separately (at reduced dose). Application of herbicide, herbicide with adjuvant and application date did not influence quality parameters of wheat grain. The highest yield of grain and weed control efficacy was obtained after preemergence, autumn application of herbicide and the highest chlortoluron residue level was determined in soil and grain samples from plots treated in spring.
\end{abstract}

Key words: chlortoluron, winter wheat, quality of grain, residue, adjuvant, application date

\section{Streszczenie}

Celem prowadzonych badań było określenie wpływu terminu aplikacji herbicydu oraz możliwości ograniczenia jego dawki przez stosowanie łącznie z adiuwantem na poziom pozostałości chlorotoluronu w glebie i ziarnie pszenicy ozimej, jak też ocena wpływu tych parametrów na jakość plonu. Badania prowadzono w latach 2010-2012 na polach produkcyjnych pszenicy ozimej. Herbicyd zawierający chlorotoluron (Tolurex $500 \mathrm{SC}$ ) stosowano samodzielnie w dawce pełnej (2,0 l/ha) i zredukowanej $(1,3 \mathrm{l} / \mathrm{ha})$ oraz w dawce zredukowanej łącznie z adiuwantami. Herbicyd stosowano przedwschodowo jesienią, późną jesienią (po ustaniu wegetacji) oraz wczesną wiosną (na różnych poletkach). W badaniach oceniono skuteczność chwastobójczą, wielkość i jakość plonu oraz pozostałości chlorotoluronu w glebie i ziarnie pszenicy. Badany herbicyd i jego mieszaniny z adiuwantami były selektywne dla roślin pszenicy ozimej odmiany Zawisza. Dodatek adiuwantów pozwolił na obniżenie dawki badanego herbicydu o 35\% zachowując jego wysoką skuteczność. Najlepszy efekt chwastobójczy oraz najwyższe plony ziarna uzyskano na obiektach opryskiwanych jesienią w zabiegu przedwschodowym. Badany herbicyd i jego mieszaniny z adiuwantami oraz termin jego stosowania nie wpłynął na jakość ziarna pszenicy ozimej. Poziom pozostałości chlorotoluronu w glebie i ziarnie pszenicy ozimej był zróżnicowany, w zależności od terminu aplikacji i dodatku adiuwantów. Wyższe pozostałości chlorotoluronu odnotowano w przypadku stosowania mieszanin z adiuwantami i na obiektach, które opryskiwano wiosną.

Key words: chlorotoluron, pszenica ozima, jakość ziarna, pozostałości, adiuwant, termin aplikacji

\footnotetext{
Instytut Uprawy Nawożenia i Gleboznawstwa - Państwowy Instytut Badawczy

Zakład Herbologii i Technik Uprawy Roli

Orzechowa 61, 50-540 Wrocław

m.kucharski@iung.wroclaw.pl
} 


\section{Wstęp / Introduction}

Zmiany w ustawodawstwie dotyczącym stosowania środków ochrony roślin (Dyrektywa 91/414/EWG 1991, 2009/128/WE 2009) wymusza poszukiwanie optymalnych rozwiązań umożliwiających ograniczenie stosowanych herbicydów i ich dawek przy jednoczesnym zachowaniu pożądanej skuteczności w regulacji zachwaszczenia.

Herbicydy w uprawie zbóż ozimych stosowane sa głównie w przed- i powschodowych zabiegach jesiennych, dzięki którym, już w początkowym okresie wegetacji eliminowane są gatunki konkurencyjne, co ma dodatni wpływ na prawidłowy rozwój i lepsze przezimowanie roślin oraz w efekcie końcowym wysokie plonowanie (Woźnica i wsp. 2004; Unay i wsp. 2006). Zdarza się jednak, że opóźniony siew lub niekorzystny przebieg pogody (obfite opady, wczesne przymrozki) uniemożliwiają planowe wykonanie zabiegów jesienią. W takich przypadkach możemy aplikować herbicydy wiosną, krótko po ruszeniu wegetacji (Woźnica 1990; Weber i wsp. 2012).

Jednym ze sposobów umożliwiających obniżenie dawki środka ochrony roślin, przy jednoczesnym zachowaniu jego skuteczności działania, jest stosowanie substancji wspomagających (adiuwantów). Są one stosowane $\mathrm{z}$ herbicydami, głównie w zabiegach nalistnych (Maschhoff i wsp. 2000; Foster i wsp. 2006). Zastosowanie adiuwantów można rozszerzyć o aplikację przedwschodową (Kucharski i Domaradzki 2008). W takich przypadkach dodatek wspomagacza ogranicza mobilność herbicydu w profilu glebowym, co wpływa korzystnie na wydłużenie czasu jego działania na chwasty (McMullan i wsp. 1998).

Celem pracy było określenie wpływu terminu aplikacji herbicydu oraz możliwości ograniczenia jego dawki poprzez stosowanie łącznie $\mathrm{z}$ adiuwantem na poziom pozostałości chlorotoluronu $\mathrm{w}$ glebie i ziarnie pszenicy ozimej, jak też ocena wpływu tych parametrów na jakość plonu.

\section{Materiały i metody / Materials and methods}

Badania prowadzono w latach 2010-2012 (dwa sezony wegetacyjne) na polu produkcyjnym pszenicy ozimej zlokalizowanym w okolicy Wrocławia (gleba o $\mathrm{pH}=5,5$; $\mathrm{C}_{\text {org }}=1,10 \%$; udział frakcji iłowej/pyłowej/piaskowej $=$ 30/27/43\%; przedplon w obu sezonach - rzepak ozimy). Doświadczenia zakładano metodą losowanych bloków, w czterech powtórzeniach, na poletkach o powierzchni $20 \mathrm{~m}^{2}$. W obu sezonach wegetacyjnych wysiano tą samą odmianę pszenicy ozimej - Zawisza. Herbicyd zawierający chlorotoluron (Tolurex $500 \mathrm{SC}$ ) stosowano w dawce pełnej $(2,0$ 1/ha) i zredukowanej $(1,3 \mathrm{l} / \mathrm{ha})$ oraz $\mathrm{w}$ dawce zredukowanej łącznie $\mathrm{z}$ adiuwantem. W mieszaninie $\mathrm{z}$ herbicydem zastosowano dwa adiuwanty różnego typu: olejowy - Atpolan Bio 80 EC (estry metylowe kwasów thuszczowych oleju rzepakowego) oraz surfaktant - Slippa (tlenek polialkilenowy modyfikowany heptametylotrisiloksanem). Herbicyd i jego mieszaniny $z$ adiuwantami stosowano przedwschodowo jesienią, późną jesienią (po ustaniu wegetacji) oraz wczesną wiosną.
Fitotoksyczność zastosowanych mieszanin oceniano bonitacyjnie (w skali 1:9) 3-4 tygodnie po aplikacji oraz wiosna po ruszeniu wegetacji. Ponadto wiosną wykonano ocenę skuteczności chwastobójczej, wykorzystując metodę szacunkową, określającą procentowe zniszczenie chwastów. Plon pszenicy ozimej zbierano kombajnem poletkowym. W ziarnie przeprowadzono analizy, określające podstawowe parametry jakościowe surowca (MTZ, masa hektolitra, wyrównanie ziarna, wskaźnik sedymentacji, liczba opadania, zawartość białka, popiołu i glutenu) oraz pozostałości substancji czynnej herbicydu. Analizy jakościowe ziarna wykonano zgodnie $\mathrm{z}$ metodyką opisana w Polskich Normach (PN-68/R-74017; BN-69/9131-02; PN-ISO 7971-2; PN-ISO 3093). Zawartość popiołu, białka, glutenu i wskaźnik sedymentacji określono za pomocą urządzenia INSTALAB 600, wykorzystującego technikę bliskiej podczerwieni NIR. Pozostałości chlorotoluronu oznaczono techniką chromatografii cieczowej HPLC/UV (PN-97/R-04123).

W statystycznym opracowaniu wyników użyto metody analizy wariancji dla doświadczeń w układzie losowanych bloków. Istotność różnic testowano wykorzystując półprzedział ufności Tukeya, a najmniejszą istotną różnicę podano dla poziomu ufności wynoszącego 0,05 . Obliczenia wykonane zostały w programie Statgraphics Centurion.

\section{Wyniki i dyskusja / Results and discussion}

Chlorotoluron, stosowany w dawce zalecanej i obniżonej, jak też łącznie $\mathrm{z}$ adiuwantami, niezależnie od terminu wykonania zabiegu, był selektywny dla roślin pszenicy ozimej odmiany Zawisza. W obu sezonach wegetacyjnych na plantacjach pszenicy dominowały gatunki chwastów, takie jak: Apera spica-venti, Stellaria media, Lamium amplexicaule, Capsella bursa-pastoris, Brassica napus i Viola arvensis. Herbicyd zastosowany w dawce pełnej zredukował chwasty na poziomie 86-97 i 80-92\%, odpowiednio dla A. spica-venti i średnio dla dominujących gatunków dwuliściennych. Obniżenie dawki herbicydu o $35 \%$ (1,3 1/ha) spowodowało spadek skuteczności chwastobójczej odpowiednio do 74-82 i 70-80\%. Zastosowanie herbicydu $\mathrm{w}$ dawce zredukowanej $\mathrm{z}$ dodatkiem adiuwantów poprawiło skuteczność działania herbicydu, a uzyskane zniszczenie chwastów kształtowało się na poziomie porównywalnym $\mathrm{z}$ tym, jakie uzyskano dla herbicydu stosowanego $\mathrm{w}$ dawce pełnej (tab. 1). Termin aplikacji herbicydu i jego mieszanin $\mathrm{z}$ adiuwantami różnicował skuteczność chwastobójczą. Najlepsze zwalczanie dominujących na polu gatunków chwastów uzyskano po wykonaniu zabiegu herbicydowego jesienią, przed wschodem rośliny uprawnej. Najsłabsze działanie herbicydu, niezależnie od dawki i dodatku adiuwanta, uzyskano po wiosennej aplikacji środków. Było to widoczne szczególnie w odniesieniu do chwastów dwuliściennych (skuteczność na poziomie 70-84\%). Podobną zależność otrzymano w stosunku do plonu ziarna pszenicy ozimej (tab. 2, 3). Najwyższe plony uzyskano z obiektów, na których aplikowano herbicydy jesienią, przedwschodowo, a najniższe wartości uzyskano z obiek tów opryskiwanych wiosna. Plon ziarna pszenicy $\mathrm{z}$ obu 
sezonów wegetacyjnych kształtował się na poziomie 3,5-4,7 t/ha i był znacząco wyższy od uzyskanego na obiektach bez ochrony herbicydowej. Dawka herbicydu i dodatek adiuwanta miał również wpływ na wielkość plonu pszenicy. Niezależnie od terminu aplikacji, obniżenie dawki herbicydu spowodowało spadek plonu pszenicy. Zastosowanie obniżonych dawek chlorotoluronu $\mathrm{z}$ dodatkiem adiuwantów umożliwiło plonowanie na poziomie obiektów, na których stosowano pełną dawkę herbicydu.

Możliwość obniżenia dawki herbicydu w łącznej aplikacji $\mathrm{z}$ adiuwantami $\mathrm{w}$ zabiegach przed- $\mathrm{i}$ powschodowych została szeroko opisana w wielu publikacjach (Schott i wsp. 1991; Krogh i wsp. 2003; Foster i wsp. 2006). Odpowiedni dobór adiuwanta, w większości przypadków umożliwiał redukcję dawki herbicydu bez wpływu na skuteczność chwastobójczą (Adamczewski i Matysiak 2005; Kucharski i wsp. 2009). Łączne stosowanie herbicydów $\mathrm{z}$ adiuwantami $\mathrm{w}$ zabiegach nalistnych wpływa korzystnie na retencję i możliwość wnikania substancji czynnej herbicydu do roślin (Foster i wsp. 2006), natomiast przy aplikacji przedwschodowej adiuwant może ograniczać przemieszczanie herbicydu w głąb profilu glebowego, co wpływa korzystnie na wydłużenie czasu, w którym herbicyd działa na wschodzące chwasty (Bayer i Foy 1982; McMullan i wsp. 1998; Kucharski i Domaradzki 2008).

Próbki ziarna pszenicy ozimej, pobrane w czasie żniw, poddano analizie jakościowej. Stosowanie herbicydu w dawce pełnej i zredukowanej, jak też łącznie $\mathrm{z}$ adiuwantami nie wpłynęło istotnie na podstawowe parametry jakościowe plonu, takie jak: masa tysiąca nasion, wyrównanie ziarna, masa hektolitra, liczba opadania, wskaźnik sedymentacji oraz zawartość białka, glutenu i popiołu (tab. 2, 3). Również wpływ terminu aplikacji herbicydu i jego mieszanin $\mathrm{z}$ adiuwantami na omawiane parametry jakościowe plonu nie został potwierdzony analizą statystyczną. Wpływ stosowania herbicydu na parametry jakościowe plonu są badane już w procesie rejestracji nowego środka. Stosowanie herbicydu może wpływać na występowanie objawów fitotoksycznych (np. przebarwienia liści, zahamowanie wzrostu). Jednak objawy te są zwykle przemijające i nie wpływają znacząco na parametry jakościowe plonu (Koeppe i wsp. 1998; Kieloch i Rola 2007; Kieloch i wsp. 2009).

Tabela 1. Ocena skuteczności działania chlorotoluronu (Tolurex 500 SC)

Table 1. Evaluation of chlortoluron (Tolurex 500 SC) efficacy

\begin{tabular}{|c|c|c|c|c|c|c|}
\hline \multirow{3}{*}{$\begin{array}{l}\text { Obiekt } \\
\text { Treatment }\end{array}$} & \multirow{3}{*}{$\begin{array}{c}\text { Dawka } \\
\text { Dose } \\
{[1 / \mathrm{ha}]}\end{array}$} & \multirow{3}{*}{$\begin{array}{c}\text { Termin aplikacji } \\
\text { Data } \\
\text { of application }\end{array}$} & \multicolumn{4}{|c|}{$\begin{array}{c}\text { Zwalczanie chwastów - Weed control } \\
{[\%]}\end{array}$} \\
\hline & & & APESV & $\begin{array}{l}\text { 2-liścienne** } \\
\text { dicot. weeds }\end{array}$ & APESV & $\begin{array}{l}\text { 2-liścienne** } \\
\text { dicot. weeds }\end{array}$ \\
\hline & & & \multicolumn{2}{|c|}{2011} & \multicolumn{2}{|c|}{2012} \\
\hline Kontrola-Untreated & - & - & $16^{*}$ & $34 *$ & $19 *$ & $42 *$ \\
\hline Tolurex $500 \mathrm{SC}$ & 2,0 & $\mathrm{~T}-0$ & 97 & 92 & 92 & 88 \\
\hline Tolurex $500 \mathrm{SC}$ & 1,3 & $\mathrm{~T}-0$ & 82 & 80 & 76 & 76 \\
\hline $\begin{array}{l}\text { Tolurex } 500 \mathrm{SC} \\
+ \text { Atpolan Bio } 80 \mathrm{EC}\end{array}$ & $\begin{array}{l}1,3 \\
1,0\end{array}$ & $\mathrm{~T}-0$ & 95 & 88 & 88 & 85 \\
\hline $\begin{array}{l}\text { Tolurex } 500 \mathrm{SC} \\
+ \text { Slippa }\end{array}$ & $\begin{array}{c}1,3 \\
0,13\end{array}$ & $\mathrm{~T}-0$ & 90 & 85 & 85 & 86 \\
\hline Tolurex $500 \mathrm{SC}$ & 2,0 & $\mathrm{~T}-2$ & 94 & 88 & 92 & 86 \\
\hline Tolurex $500 \mathrm{SC}$ & 1,3 & $\mathrm{~T}-2$ & 80 & 78 & 78 & 74 \\
\hline $\begin{array}{l}\text { Tolurex } 500 \mathrm{SC} \\
+ \text { Atpolan Bio } 80 \mathrm{EC}\end{array}$ & $\begin{array}{l}1,3 \\
1,0\end{array}$ & $\mathrm{~T}-2$ & 88 & 86 & 88 & 85 \\
\hline $\begin{array}{l}\text { Tolurex } 500 \mathrm{SC} \\
+ \text { Slippa }\end{array}$ & $\begin{array}{c}1,3 \\
0,13\end{array}$ & $\mathrm{~T}-2$ & 86 & 82 & 85 & 84 \\
\hline Tolurex $500 \mathrm{SC}$ & 2,0 & $\mathrm{~T}-4$ & 90 & 84 & 86 & 80 \\
\hline Tolurex $500 \mathrm{SC}$ & 1,3 & $\mathrm{~T}-4$ & 74 & 70 & 74 & 70 \\
\hline $\begin{array}{l}\text { Tolurex } 500 \mathrm{SC} \\
+ \text { Atpolan Bio } 80 \mathrm{EC}\end{array}$ & $\begin{array}{l}1,3 \\
1,0\end{array}$ & $\mathrm{~T}-4$ & 86 & 76 & 83 & 75 \\
\hline $\begin{array}{l}\text { Tolurex } 500 \mathrm{SC} \\
+ \text { Slippa }\end{array}$ & $\begin{array}{c}1,3 \\
0,13\end{array}$ & $\mathrm{~T}-4$ & 82 & 72 & 80 & 76 \\
\hline
\end{tabular}

*dla kontroli podano liczbę chwastów na $\mathrm{m}^{2}$ - for untreated the number of weeds per $\mathrm{m}^{2}$ is given

**suma chwastów dwuliściennych - sum of dicotyledonous weeds: (Brassica napus, Stellaria media, Viola arvensis,

Thlaspi arvense, Lamium amplexicaule, Capsella bursa-pastoris)

APESV - Apera spica-venti

T-0, T-2, T-4 - termin wykonania zabiegu, odpowiednio: jesienią - przedwschodowo, późną jesienią (po ustaniu wegetacji) i wczesną wiosną data of herbicide application, respectively: preemergence in the autumn, post emergence in the late autumn and in the spring 
Tabela 2. Parametry jakościowe ziarna pszenicy ozimej (sezon 2010/2011)

Table 2. Quality parameters of winter wheat grain (season 2010/2011)

\begin{tabular}{|c|c|c|c|c|c|c|c|c|c|c|c|}
\hline \multirow[b]{2}{*}{$\begin{array}{l}\text { Obiekt } \\
\text { Treatment }\end{array}$} & \multirow[b]{2}{*}{$\begin{array}{c}\text { Dawka } \\
\text { Dose } \\
{[1 / \mathrm{ha}]}\end{array}$} & \multirow{2}{*}{$\begin{array}{c}\text { Termin } \\
\text { aplikacji } \\
\text { Data of } \\
\text { application }\end{array}$} & \multicolumn{9}{|c|}{ Parametry jakościowe - Quality parameters } \\
\hline & & & $\begin{array}{c}\text { plon } \\
\text { yield } \\
{[\mathrm{t} / \mathrm{ha}]}\end{array}$ & $\begin{array}{c}\text { białko } \\
\text { protein } \\
{[\%]}\end{array}$ & $\begin{array}{c}\text { gluten } \\
\text { gluten } \\
{[\%]}\end{array}$ & $\begin{array}{c}\text { popiół } \\
\text { ash } \\
{[\%]}\end{array}$ & $\begin{array}{c}\text { MTN } \\
{[\mathrm{g}]}\end{array}$ & $\begin{array}{l}\text { SR } \\
{[\%]}\end{array}$ & $\begin{array}{l}\mathrm{WN} \\
{[\%]}\end{array}$ & $\begin{array}{l}\mathrm{LO} \\
{[\mathrm{s}]}\end{array}$ & $\begin{array}{c}\mathrm{hL} \\
{[\mathrm{kg} / \mathrm{hl}]}\end{array}$ \\
\hline Kontrola - Untreated & - & - & 3,42 & 11,5 & 27,2 & 1,32 & 41,0 & 28,1 & 95,0 & 280 & 75,1 \\
\hline Tolurex $500 \mathrm{SC}$ & 2,0 & $\mathrm{~T}-0$ & 4,68 & 11,2 & 27,8 & 1,38 & 41,7 & 27,8 & 95,4 & 268 & 75,8 \\
\hline Tolurex $500 \mathrm{SC}$ & 1,3 & $\mathrm{~T}-0$ & 4,22 & 12,1 & 27,5 & 1,34 & 41,3 & 27,7 & 95,4 & 265 & 74,9 \\
\hline $\begin{array}{l}\text { Tolurex } 500 \mathrm{SC} \\
+ \text { Atpolan Bio } 80 \mathrm{EC}\end{array}$ & $\begin{array}{l}1,3 \\
1,0\end{array}$ & $\begin{array}{l}\text { T-0 } \\
\text { T-0 }\end{array}$ & 4,60 & 11,3 & 27,6 & 1,29 & 41,8 & 28,0 & 95,6 & 274 & 75,8 \\
\hline $\begin{array}{l}\text { Tolurex } 500 \mathrm{SC} \\
+ \text { Slippa }\end{array}$ & $\begin{array}{c}1,3 \\
0,13\end{array}$ & $\begin{array}{l}\mathrm{T}-0 \\
\mathrm{~T}-0\end{array}$ & 4,52 & 11,6 & 27,1 & 1,38 & 41,1 & 27,3 & 95,7 & 280 & 75,5 \\
\hline Tolurex $500 \mathrm{SC}$ & 2,0 & $\mathrm{~T}-2$ & 4,52 & 11,2 & 26,8 & 1,32 & 41,6 & 27,5 & 96,3 & 289 & 76,2 \\
\hline Tolurex $500 \mathrm{SC}$ & 1,3 & $\mathrm{~T}-2$ & 4,14 & 10,9 & 26,2 & 1,24 & 40,9 & 27,0 & 96,8 & 291 & 74,6 \\
\hline $\begin{array}{l}\text { Tolurex } 500 \mathrm{SC} \\
+ \text { Atpolan Bio } 80 \mathrm{EC}\end{array}$ & $\begin{array}{l}1,3 \\
1,0\end{array}$ & $\begin{array}{l}\text { T-2 } \\
\text { T-2 }\end{array}$ & 4,36 & 11,7 & 27,1 & 1,20 & 41,5 & 27,9 & 96,1 & 287 & 74,9 \\
\hline $\begin{array}{l}\text { Tolurex } 500 \text { SC } \\
+ \text { Slippa }\end{array}$ & $\begin{array}{c}1,3 \\
0,13\end{array}$ & $\begin{array}{l}\text { T-2 } \\
\text { T-2 }\end{array}$ & 4,30 & 11,2 & 26,5 & 1,29 & 41,0 & 28,2 & 95,2 & 270 & 75,6 \\
\hline Tolurex $500 \mathrm{SC}$ & 2,0 & $\mathrm{~T}-4$ & 4,30 & 10,8 & 26,9 & 1,37 & 39,8 & 28,5 & 95,7 & 265 & 76,1 \\
\hline Tolurex $500 \mathrm{SC}$ & 1,3 & $\mathrm{~T}-4$ & 3,93 & 11,3 & 27,9 & 1,40 & 40,5 & 28,0 & 96,9 & 272 & 75,9 \\
\hline $\begin{array}{l}\text { Tolurex } 500 \mathrm{SC} \\
+ \text { Atpolan Bio } 80 \mathrm{EC}\end{array}$ & $\begin{array}{l}1,3 \\
1,0\end{array}$ & $\begin{array}{l}\text { T-4 } \\
\text { T-4 }\end{array}$ & 4,12 & 11,8 & 27,2 & 1,34 & 41,2 & 27,6 & 96,7 & 284 & 75,2 \\
\hline $\begin{array}{l}\text { Tolurex } 500 \text { SC } \\
+ \text { Slippa }\end{array}$ & $\begin{array}{c}1,3 \\
0,13\end{array}$ & $\begin{array}{l}\mathrm{T}-4 \\
\mathrm{~T}-4\end{array}$ & 4,09 & 12,0 & 26,5 & 1,26 & 41,5 & 27,2 & 95,5 & 290 & 76,3 \\
\hline \multicolumn{3}{|c|}{$\operatorname{NIR}(0,05)-\operatorname{LSD}(0.05)$} & 0,316 & 1,42 & 1,92 & 0,226 & 2,18 & 1,76 & 2,14 & 28,4 & 1,60 \\
\hline
\end{tabular}

MTN - masa tysiąca nasion - thousand grain weight [g]

$\mathrm{SR}$ - wskaźnik sedymentacji - sedimentation rate [\%]

WN - wyrównanie ziarna - seed grading [\%]

LO - liczba opadania - falling number [s]

$\mathrm{hL}$ - masa hektolitra - weight of hectoliter $[\mathrm{kg} / \mathrm{hl}]$

T-0, T-2, T-4 - termin wykonania zabiegu, odpowiednio: jesienia - przedwschodowo, późna jesienią (po ustaniu wegetacji) i wczesną wiosną -

data of herbicide application, respectively: preemergence in the autumn, post emergence in the late autumn and in the spring

Tabela 3. Parametry jakościowe ziarna pszenicy ozimej (sezon 2011/2012)

Table 3. Quality parameters of winter wheat grain (season 2011/2012)

\begin{tabular}{|c|c|c|c|c|c|c|c|c|c|c|c|}
\hline \multirow[b]{2}{*}{$\begin{array}{l}\text { Obiekt } \\
\text { Treatment }\end{array}$} & \multirow{2}{*}{$\begin{array}{l}\text { Dawka } \\
\text { Dose } \\
{[1 / \text { ha }]}\end{array}$} & \multirow{2}{*}{$\begin{array}{c}\text { Termin } \\
\text { aplikacji } \\
\text { Data of } \\
\text { application }\end{array}$} & \multicolumn{9}{|c|}{ Parametry jakościowe - Quality parameters } \\
\hline & & & $\begin{array}{l}\text { plon } \\
\text { yield } \\
\text { [t/ha] }\end{array}$ & $\begin{array}{c}\text { białko } \\
\text { protein } \\
{[\%]}\end{array}$ & $\begin{array}{c}\text { gluten } \\
\text { gluten } \\
{[\%]}\end{array}$ & $\begin{array}{c}\text { popiół } \\
\text { ash } \\
{[\%]}\end{array}$ & $\begin{array}{c}\text { MTN } \\
{[\mathrm{g}]}\end{array}$ & $\begin{array}{c}\mathrm{SR} \\
{[\%]}\end{array}$ & $\begin{array}{l}\mathrm{WN} \\
{[\%]}\end{array}$ & $\begin{array}{l}\mathrm{LO} \\
{[\mathrm{s}]}\end{array}$ & $\begin{array}{c}\mathrm{hL} \\
{[\mathrm{kg} / \mathrm{hl}]}\end{array}$ \\
\hline 1 & 2 & 3 & 4 & 5 & 6 & 7 & 8 & 9 & 10 & 11 & 12 \\
\hline Kontrola - Untreated & - & - & 3,18 & 10,7 & 24,8 & 0,85 & 39,2 & 32,6 & 98,0 & 305 & 80,1 \\
\hline Tolurex $500 \mathrm{SC}$ & 2,0 & $\mathrm{~T}-0$ & 4,22 & 11,3 & 26,5 & 0,80 & 38,4 & 32,1 & 97,6 & 312 & 81,7 \\
\hline Tolurex $500 \mathrm{SC}$ & 1,3 & $\mathrm{~T}-0$ & 3,80 & 10,2 & 25,3 & 0,72 & 38,9 & 31,2 & 98,5 & 298 & 81,6 \\
\hline $\begin{array}{l}\text { Tolurex } 500 \mathrm{SC} \\
+ \text { Atpolan Bio } 80 \mathrm{EC}\end{array}$ & $\begin{array}{l}1,3 \\
1,0\end{array}$ & $\begin{array}{l}\mathrm{T}-0 \\
\mathrm{~T}-0\end{array}$ & 4,08 & 11,0 & 24,6 & 0,94 & 39,6 & 33,1 & 97,8 & 306 & 80,2 \\
\hline $\begin{array}{l}\text { Tolurex } 500 \mathrm{SC} \\
+ \text { Slippa }\end{array}$ & $\begin{array}{c}1,3 \\
0,13\end{array}$ & $\begin{array}{l}\mathrm{T}-0 \\
\mathrm{~T}-0\end{array}$ & 4,02 & 10,9 & 26,1 & 0,90 & 39,2 & 32,6 & 96,9 & 310 & 79,1 \\
\hline Tolurex $500 \mathrm{SC}$ & 2,0 & $\mathrm{~T}-2$ & 4,08 & 10,5 & 25,8 & 0,75 & 38,9 & 33,4 & 97,3 & 302 & 81,3 \\
\hline Tolurex $500 \mathrm{SC}$ & 1,3 & $\mathrm{~T}-2$ & 3,60 & 9,9 & 26,3 & 0,84 & 39,0 & 31,8 & 97,8 & 291 & 80,5 \\
\hline $\begin{array}{l}\text { Tolurex } 500 \mathrm{SC} \\
+ \text { Atpolan Bio } 80 \mathrm{EC}\end{array}$ & $\begin{array}{l}1,3 \\
1,0\end{array}$ & $\begin{array}{l}\text { T-2 } \\
\text { T-2 }\end{array}$ & 3,98 & 10,7 & 25,7 & 0,89 & 38,1 & 32,0 & 98,1 & 297 & 79,6 \\
\hline $\begin{array}{l}\text { Tolurex } 500 \mathrm{SC} \\
+ \text { Slippa }\end{array}$ & $\begin{array}{c}1,3 \\
0,13\end{array}$ & $\begin{array}{l}\text { T-2 } \\
\text { T-2 }\end{array}$ & 3,90 & 10,5 & 24,9 & 0,92 & 38,6 & 32,5 & 97,6 & 308 & 80,2 \\
\hline
\end{tabular}




\begin{tabular}{l|c|c|c|c|c|c|c|c|c|c|c}
\hline \multicolumn{1}{c|}{1} & 2 & 3 & 4 & 5 & 6 & 7 & 8 & 9 & 10 & 11 & 12 \\
\hline Tolurex 500 SC & 2,0 & T-4 & 3,96 & 11,1 & 25,0 & 0,76 & 39,5 & 33,1 & 97,0 & 315 & 80,7 \\
\hline Tolurex 500 SC & 1,3 & T-4 & 3,50 & 9,8 & 25,2 & 0,80 & 39,8 & 32,9 & 96,8 & 319 & 81,2 \\
\hline $\begin{array}{l}\text { Tolurex 500 SC } \\
+ \text { Atpolan Bio 80 EC }\end{array}$ & $\begin{array}{c}1,3 \\
1,0\end{array}$ & $\begin{array}{c}\text { T-4 } \\
\text { T-4 }\end{array}$ & 3,69 & 10,6 & 25,8 & 0,91 & 39,0 & 32,4 & 97,4 & 294 & 80,9 \\
\hline $\begin{array}{l}\text { Tolurex 500 SC } \\
+ \text { Slippa }\end{array}$ & 1,3 & T-4 & 3,62 & 10,0 & 26,3 & 0,83 & 38,4 & 31,7 & 97,9 & 292 & 79,6 \\
\hline NIR (0,05)-LSD (0.05) & & T-4 & 0,392 & 1,67 & 2,07 & 0,264 & 2,08 & 2,46 & 1,95 & 30,2 & 2,92 \\
\hline
\end{tabular}

MTN - masa tysiąca nasion - thousand grain weight [g]

$\mathrm{SR}$ - wskaźnik sedymentacji - sedimentation rate [\%]

WN - wyrównanie ziarna - seed grading [\%]

LO - liczba opadania - falling number [s]

$\mathrm{hL}$ - masa hektolitra - weight of hectoliter $[\mathrm{kg} / \mathrm{hl}]$

T-0, T-2, T-4 - termin wykonania zabiegu, odpowiednio: jesienią - przedwschodowo, późną jesienią (po ustaniu wegetacji) i wczesną wiosną -

data of herbicide application, respectively: preemergence in the autumn, post emergence in the late autumn and in the spring

Tabela 4. Pozostałości chlorotoluronu w glebie i ziarnie pszenicy ozimej

Table 4. Residues of chlortoluron in soil and grain of winter wheat

\begin{tabular}{|c|c|c|c|c|c|c|}
\hline \multirow{3}{*}{$\begin{array}{c}\text { Obiekt } \\
\text { Treatment }\end{array}$} & \multirow{3}{*}{$\begin{array}{c}\text { Dawka } \\
\text { Dose } \\
{[1 / \mathrm{ha}]}\end{array}$} & \multirow{3}{*}{$\begin{array}{c}\text { Termin aplikacji } \\
\text { Data of application }\end{array}$} & \multicolumn{4}{|c|}{$\begin{array}{c}\text { Pozostałości - Residues } \\
{[\mathrm{mg} / \mathrm{kg}]}\end{array}$} \\
\hline & & & \multicolumn{2}{|c|}{ gleba - soil } & \multicolumn{2}{|c|}{ ziarno - grain } \\
\hline & & & 2011 & 2012 & 2011 & 2012 \\
\hline Tolurex $500 \mathrm{SC}$ & 2,0 & $\mathrm{~T}-0$ & 0,0012 & 0,0016 & 0,0009 & 0,0012 \\
\hline Tolurex $500 \mathrm{SC}$ & 1,3 & $\mathrm{~T}-0$ & NW & 0,0005 & NW & NW \\
\hline $\begin{array}{l}\text { Tolurex } 500 \mathrm{SC} \\
+ \text { Atpolan Bio } 80 \mathrm{EC}\end{array}$ & $\begin{array}{l}1,3 \\
1,0 \\
\end{array}$ & $\begin{array}{l}\text { T-0 } \\
\text { T-0 }\end{array}$ & 0,0008 & 0,0011 & 0,0005 & 0,0008 \\
\hline $\begin{array}{l}\text { Tolurex } 500 \mathrm{SC} \\
+ \text { Slippa }\end{array}$ & $\begin{array}{c}1,3 \\
0,13\end{array}$ & $\begin{array}{l}\text { T-0 } \\
\text { T-0 }\end{array}$ & 0,0007 & 0,0009 & NW & 0,0005 \\
\hline Tolurex $500 \mathrm{SC}$ & 2,0 & $\mathrm{~T}-2$ & 0,0016 & 0,0019 & 0,0012 & 0,0014 \\
\hline Tolurex $500 \mathrm{SC}$ & 1,3 & $\mathrm{~T}-2$ & 0,0007 & 0,0010 & NW & 0,0005 \\
\hline $\begin{array}{l}\text { Tolurex } 500 \mathrm{SC} \\
+ \text { Atpolan Bio } 80 \mathrm{EC}\end{array}$ & $\begin{array}{l}1,3 \\
1,0\end{array}$ & $\begin{array}{l}\mathrm{T}-2 \\
\mathrm{~T}-2\end{array}$ & 0,0010 & 0,0014 & 0,0008 & 0,0010 \\
\hline $\begin{array}{l}\text { Tolurex } 500 \mathrm{SC} \\
+ \text { Slippa }\end{array}$ & $\begin{array}{c}1,3 \\
0,13\end{array}$ & $\begin{array}{l}\mathrm{T}-2 \\
\mathrm{~T}-2\end{array}$ & 0,0008 & 0,0012 & 0,0006 & 0,0007 \\
\hline Tolurex $500 \mathrm{SC}$ & 2,0 & $\mathrm{~T}-4$ & 0,0020 & 0,0024 & 0,0013 & 0,0017 \\
\hline Tolurex $500 \mathrm{SC}$ & 1,3 & $\mathrm{~T}-4$ & 0,0011 & 0,0014 & 0,0005 & 0,0007 \\
\hline $\begin{array}{l}\text { Tolurex } 500 \mathrm{SC} \\
+ \text { Atpolan Bio } 80 \mathrm{EC} \\
\end{array}$ & $\begin{array}{l}1,3 \\
1,0 \\
\end{array}$ & $\begin{array}{l}\mathrm{T}-4 \\
\mathrm{~T}-4 \\
\end{array}$ & 0,0016 & 0,0019 & 0,0010 & 0,0013 \\
\hline $\begin{array}{l}\text { Tolurex } 500 \mathrm{SC} \\
+ \text { Slippa }\end{array}$ & $\begin{array}{c}1,3 \\
0,13\end{array}$ & $\begin{array}{l}\mathrm{T}-4 \\
\mathrm{~T}-4\end{array}$ & 0,0013 & 0,0016 & 0,0007 & 0,0010 \\
\hline \multicolumn{3}{|l|}{$\operatorname{NIR}(0,05)-\operatorname{LSD}(0.05)$} & 0,00032 & 0,00039 & 0,00023 & 0,00027 \\
\hline
\end{tabular}

T-0, T-2, T-4 - termin wykonania zabiegu, odpowiednio: jesienią - przedwschodowo, późną jesienią (po ustaniu wegetacji) i wczesną wiosną data of herbicide application, respectively: preemergence in the autumn, post emergence in the late autumn and in the spring $\mathrm{NW}$ - pozostałości nie wykryto $(<0,0005 \mathrm{mg} / \mathrm{kg})-$ residue did not detect $(<0.0005 \mathrm{mg} / \mathrm{kg})$

W próbkach gleby i ziarna pszenicy ozimej, pobranych w czasie zbioru, wykonano również badania na obecność pozostałości chlorotoluronu. W próbkach gleby pozostałości kształtowały się w granicach od niewykrywalnych [NW - poniżej progu oznaczalności metody analitycznej $(<0,0005 \mathrm{mg} / \mathrm{kg})]$ do $0,0024 \mathrm{mg} / \mathrm{kg}$, natomiast w próbkach ziarna od NW do $0,0017 \mathrm{mg} / \mathrm{kg}$. Poziom pozostałości chlorotoluronu $\mathrm{w}$ glebie i ziarnie pszenicy był zróżnicowany i zależny od terminu wykonanego zabiegu, dawki herbicydu i obecności adiuwanta (tab. 4). Najniższe pozostałości odnotowano w próbkach gleby i ziarna, które pochodziły $\mathrm{z}$ obiektów opryskiwanych jesienią w zabiegu przedwschodowym. Najwyższe pozostałości chlorotoluronu wykryto $\mathrm{w}$ próbkach pochodzących $\mathrm{z}$ zabiegu wiosennego. Różnice pomiędzy pozostałościami oznaczonymi $\mathrm{w}$ próbkach $\mathrm{z}$ obu terminów były istotne statystycznie. Niezależnie od terminu wykonania zabiegu, najwyższe pozostałości chlorotoluronu (gleba i ziarno) odnotowano na obiektach opryskanych pełną dawką herbicydu. Redukcja dawki herbicydu powodowała również istotne obniżenie stężenia pozostałości. W przypadku zastosowania herbicydu w dawce zredukowanej 
z dodatkiem adiuwanta obserwowano wzrost pozostałości, jednak ich poziom był niższy od tego, jaki stwierdzono na obiektach z pełną dawką herbicydu (tab. 4). Dotychczasowe wyniki badań wskazuja, że stosowanie herbicydów $\mathrm{z}$ adiuwantami może wpływać na dynamikę zanikania, jak też wzrost pozostałości herbicydów w glebie i materiale roślinnym (Swarcewicz i wsp. 1998; Kucharski 2003; Kucharski i Sadowski 2006; Kucharski i Domaradzki 2008). Wykryte $\mathrm{w}$ badaniach pozostałości chlorotoluronu w ziarnie pszenicy ozimej, niezależnie od dawki i sposobu aplikacji herbicydu, były znacząco niższe od wartości dopuszczalnych (Najwyższe Dopuszczalne Pozostałości NDP) (Rozporządzenie 2007).

\section{Wnioski / Conclusions}

1. Najwyższą skuteczność w zwalczaniu chwastów uzyskano stosując chlorotoluron $\mathrm{w}$ dawce pełnej oraz obniżonej $\mathrm{z}$ dodatkiem adiuwantów $\mathrm{w}$ zabiegu jesiennym - przedwschodowym.

2. Zastosowanie adiuwantów umożliwiło obniżenie dawki chlorotoluronu o $35 \%$ z zachowaniem skuteczności chwastobójczej zbliżonej do poziomu uzyskanego po stosowaniu dawki pełnej.
3. Najwyższe plony pszenicy ozimej uzyskano z obiektów, na których zastosowano chlorotoluron $w$ dawce pełnej oraz obniżonej $\mathrm{z}$ dodatkiem adiuwantów w zabiegu jesiennym - przedwschodowym.

4. Termin stosowania herbicydów, jak też dodatek adiuwanta, nie wpłynął na badane cechy jakościowe ziarna. Badane parametry nie różniły się istotnie od tych, które uzyskano w pszenicy rosnącej na obiektach kontrolnych (bez zabiegów herbicydowych).

5. Najniższe pozostałości chlorotoluronu, w glebie i ziarnie pszenicy, odnotowano w próbkach pochodzących z obiektów opryskiwanych jesienią - przedwschodowo.

6. Dodatek adiuwanta powodował wzrost pozostałości chlorotoluronu $\mathrm{w}$ porównaniu $\mathrm{z}$ obiektami, na których stosowano sam herbicyd (w dawce zredukowanej), niezależnie od terminu aplikacji.

7. Poziom oznaczonych pozostałości chlorotoluronu (we wszystkich próbkach ziarna) był niższy od wartości dopuszczalnych (NDP), określonych w normach.

Prezentowane badania wykonano w ramach zadania 2.6 Programu Wieloletniego Instytutu Uprawy Nawożenia i Gleboznawstwa - Państwowego Instytutu Badawczego.

\section{Literatura / References}

Adamczewski K., Matysiak R. 2005. Znaczenie i korzyści wynikające ze stosowania adiuwantów z herbicydami sulfonylomocznikowymi. [The effects and benefits of adjuvant used with sulfonylurea herbicides]. Prog. Plant Prot./Post. Ochr. Roślin 45 (1): $17-24$.

Bayer D.E., Foy C.L. 1982. Action and fate of adjuvants in soils. Weed Sci. 34: 84-92.

BN-69/9131-02. 1969. Oznaczanie wyrównania ziarna.

Dyrektywa 91/414/EWG z dnia 15 lipca 1991 dotycząca wprowadzania do obrotu środków ochrony roślin. Dz. U. WE, L 230/1 z dn. 19.08.1991, $32 \mathrm{ss}$.

Dyrektywa 2009/128/WE z dnia 21 października 2009 ustalająca ramy wspólnego działania na rzecz zrównoważonego stosowania pestycydów. Dz. U. WE, L 309/71 z dn. 24.11.2009, 71 ss.

Foster D.K., Taylor W.A., Parsons R.G. 2006. Effects of adjuvants on the deposition, retention and efficacy of pesticides. Aspects Appl. Biol. 77 (1): 127-132.

Kieloch R., Rola H. 2007. Wpływ herbicydów na plonowanie wybranych odmian pszenicy ozimej. Inż. Rol. 3 (91): 99-103.

Kieloch R., Rola H., Sumisławska J., Marczewski K. 2009. Chemiczna ochrona zbóż przed chwastami a jakość ziarna. [Chemical weed control and technological quality of winter wheat and rye grain]. Prog. Plant Prot./Post. Ochr. Roślin 49 (2): 938-945.

Koeppe M.K., Barefoot A.C., Cotterman C.D., Zimmerman W.T., Leep D.C. 1998. Basis of selectivity of the herbicide flupyrsulfuronmethyl in wheat. Pest. Biochem. Physiol. 59: 105-117.

Krogh K.A., Halling-Sorensen B., Mogensen B.B., Vejrup K.V. 2003. Environmental properties and effects of nonionic surfactant adjuvants in pesticides: a review. Chemosphere 50: 871-901.

Kucharski M. 2003. Influence of herbicide and adjuvant application on residues in soil and plant of sugar beet. J. Plant Prot. Res. 43 (3): $225-232$.

Kucharski M., Domaradzki K. 2008. Stosowanie adiuwantów z metamitronem w zabiegach przedwschodowych - wpływ na skuteczność chwastobójczą oraz pozostałości herbicydu w glebie. [Adjuvants with metamitron in preemergence treatment - influence on weed control efficacy and herbicide residues in soil]. Prog. Plant Prot./Post. Ochr. Roślin 48 (1): 281-286.

Kucharski M., Naraniecki B., Domaradzki K. 2009. Oksyetylowana frakcja glicerynowa z instalacji biodiesla - surowiec ekologicznych adiuwantów dla herbicydów. [Oxyethylated glicerol fraction from biodiesel fuel system as ecological adjuvant material for herbicides]. Prog. Plant Prot./Post. Ochr. Roślin 49 (2): 900-903.

Kucharski M., Sadowski J. 2006. Effect of adjuvants on herbicide residues level in soil and plant. J. Plant Dis. Prot. 20: 971-975.

Maschhoff J.R., Hart S.E., Baldwin J. 2000. Effect of ammonium sulfate on the efficacy, absorption, and translocation of glufosinate. Weed Sci. 48 (1): 2-6.

McMullan P.M., Thomas J.M., Volgas G. 1998. HM9679 - A spray adjuvant for soil-applied herbicides. p. 285-290. In: Proc. 5th International Symposium on Adjuvants for Agrochemicals. USA, Memphis, Tennessee, 17-21 August 1998, 519 pp.

PN-68/R-74017. 1968. Oznaczanie masy 1000 ziarn.

PN-97/R-04123. 1997. Gleba i materiał roślinny. Oznaczanie pozostałości herbicydów. Substancja aktywna - pochodne fenylomocznika. 
PN-ISO 3093. 1996. Oznaczanie liczby opadania.

PN-ISO 7971-2. 1998. Oznaczanie gęstości w stanie zsypnym, zwanej „masą hektolitra”.

Rozporządzenie Ministra Zdrowia z dnia 16 maja 2007 r. w sprawie najwyższych dopuszczalnych poziomów pozostałości pestycydów, które mogą znajdować się w środkach spożywczych lub na ich powierzchni (Dz. U. Nr 119, poz. 817 z późn. zm.).

Schott J.J., Dufour J.L., Gauvrit C. 1991. Effects of adjuvants on herbicidal action. III. Effects of petroleum and rapeseed oils on diclofop-methyl action on ryegrass. Agronomie 11 (1): 27-34.

Swarcewicz M., Muliński Z., Zbieć I. 1998. Influence of spray adjuvants on the behavior of trifluralin in the soil. Bull. Environ. Contam. Toxicol. 60: 569-574.

Unay A., Dogan M.N., Boz O. 2006. Effects of different herbicides and applications times on the apical development and grain yield of wheat (Triticum aestivum L.). J. Plant Dis. Prot. 20: 795-799.

Weber R., Gołębiowska H., Bortniak M. 2012. Zmienność liczebności chwastów segetalnych w okresie wiosennym w zależności od wysokości ścierni przedplonu i sposobu uprawy roli kilku odmian pszenicy ozimej. Zesz. Nauk. UP Wrocław, Rolnictwo 585: 141-150.

Woźnica Z. 1990. Jesienne i wiosenne stosowanie chlorsulfuronu w pszenicy ozimej. Rocz. Nauk Rol. Seria E, 20 (1-2): 117-122.

Woźnica Z., Waniorek W., Miłkowski P. 2004. Wpływ sposobu stosowania herbicydów na zachwaszczenie i plony ziarna pszenicy ozimej. Acta Sci. Pol., Agricultura 3 (1): 37-44. 